\title{
Apoptotic activity of fatty acid derivatives may correlate with their inhibition of DNA replication
}

\author{
CHUNHUI MIAO ${ }^{1,2}$, JUAN DU $^{1,2}$, HUNG THE DANG ${ }^{4}$, IN-HYE JEONG ${ }^{1}$, \\ SONG YOU ${ }^{2}$, JANG-SU PARK ${ }^{3}$, JEE H. JUNG ${ }^{4}$ and DONG-KYOO KIM ${ }^{1}$ \\ ${ }^{1}$ Department of Biomedicinal Chemistry and Institute of Functional Materials, Inje University, 607 Aubang-dong, \\ Gimhae 621-749, Korea; ${ }^{2}$ School of Pharmaceutical Engineering, Shenyang Pharmaceutical University, \\ Shenyang 110016, P.R. China; ${ }^{3}$ Department of Chemistry and Centre for Innovative Bio-physio \\ Sensor Technology, ${ }^{4}$ College of Pharmacy, Pusan National University, Busan 609-735, Korea
}

Received April 7, 2008; Accepted June 12, 2008

DOI: 10.3892/ijo_00000120

\begin{abstract}
The apoptogenic and DNA damaging effects of $(E)$-10-oxooctadec-8-enoic acid (S5C) and (E)-9-oxooctadec10-enoic acid (S6C), two structurally related fatty acids isolated from Red Alga Gracilaria verrucosa, were compared and their apoptosis-inducing properties characterized against human lung carcinoma (A549) cells. Significantly, the two acids decreased the rates of proliferation and viability $\left(\mathrm{IC}_{50}\right.$ of $\sim 170$ and $\sim 140 \mu \mathrm{M}$ ) as well as evidence of the induction of apoptosis. Cell morphological changes observed under light microscopy confirmed apoptosis occurrence. The results from Annexin V/PI dual staining and the cell cycle arrest assay indicated that S5C and S6C induced an earlier apoptosis of A549 cells in a concentration-dependent manner. We found that they induced DNA damage and inhibited DNA replication followed by $\mathrm{S}$-phase arrest. In addition, the very sensitive alkaline micro-gel electrophoresis technique (comet assay) was used to estimate the compound-induced DNA single- and double-strand breaks. These findings suggest that S5C and S6C induced A549 cell apoptosis and their effects are associated with DNA damage. Therefore, S5C and S6C have the potential to be developed into anticancer agents due to their relatively easy synthesis and structural manipulation.
\end{abstract}

\section{Introduction}

The search for new drugs designed for anticancer chemotherapy, as well as the discovery of novel targets for such treatment is currently being investigated. It is well recognized

Correspondence to: Dr Dong-Kyoo Kim, Department of Biomedicinal Chemistry and Institute of Functional Materials, Inje University, 607 Aubang-dong, Gimhae 621-749, Korea

E-mail: chemkdg@inje.ac.kr

Key words: fatty acid derivatives, apoptosis, DNA damage, DNA replication that $60 \%$ of the agents used as drugs for cancer treatment are substances of natural origin (1). Moreover, the analysis of empirically isolated natural substances and their specially designed derivatives became a potential tool for discovering principally innovative intracellular targets for anticancer drugs.

The marine environment is an exceptional reservoir of bioactive natural products, many of which exhibit unique structural/chemical features since its physical and chemical conditions are very distinctive from those of the terrestrial environment. In recent years, the marine environment has proven to be a very rich source of markedly potent compounds that have demonstrated significant properties in anticancer, anti-inflammatory, analgesia, immunomodulation, allergy and anti-viral assays. Except for the three drugs of marine origin: cephalosporins, cytarabine (Ara-C) and vidarabine (Ara-C), which are already well-established on the market (2), bryostatin-1, squalamine and ET743 have been granted Orphan Drug status in the previous 2 years (3).

The compounds $(E)$-10-oxooctadec-8-enoic acid (S5C) and $(E)$-9-oxooctadec-10-enoic acid (S6C) were isolated from the Red Alga Gracilaria verrucosa. The two compounds showed significant inhibitory effects on the production of major pro-inflammatory mediators (such as NO, IL-6 and TNF- $\alpha$ ) (4). Previously, compounds S5C and S6C were only isolated from the airway cells of cotton workers and showed inhibitory effects on various cancer cell lines (such as HL-60, U-937 promyelocytes and Eagle's KB carcinoma cells) (5). However, their biological properties with regard to antiproliferative effects and molecular mechanisms for therapeutic effects have been poorly examined.

Many reports demonstrated that DNA damage was induced in cancer cells by exposure to chemotherapy drugs $(6,7)$, and that DNA strand breakage may be one reason for DNA lesions, which can be sensitively detected in anticancer studies by the comet assay (8). The alkaline comet assay detects DNA single- and double-strand breaks, alkali-labile sites, and incomplete excision repair sites. Consequently, versions of the assay have been developed for specific types of DNA damage (e.g., oxidative lesions) and for detecting DNA damage in numerous types of cells (9). However, responding to DNA, damaged cells may choose many pathways, such as 
undergoing cell cycle arrest, to facilitate DNA repair, or by undergoing apoptosis $(10,11)$.

Apoptosis has been characterized as a fundamental cellular activity which maintains the physiological balance of the organism. It is involved in immune defence mechanisms (12) that play a necessary role in protecting against carcinogenesis by eliminating damaged or abnormal excess cells which have proliferated owing to the induction of various chemical agents $(12,13)$. Morphologically, apoptosis is characterized by shrinkage of the cell, dramatic reorganization of the nucleus, active membrane blebbing, and, ultimately, fragmentation of the cell into membrane-enclosed vesicles (apoptotic bodies) (14). In the early stage of apoptosis, the membrane phospholipid phosphatidylserine (PS) is translocated from the inner to the outer leaflet. Annexin V has a high affinity for PS, which identifies apoptosis at this earlier stage.

Emerging evidence has demonstrated that the anticancer properties of certain chemotherapeutic agents are involved in the induction of apoptosis, which is regarded as the preferred way of treating cancer (15). Therefore, it is essential to identify novel apoptosis-inducing compounds that are candidates as antitumor agents. Similarly, small molecules, such as S5C and $\mathrm{S} 6 \mathrm{C}$ have a great potential to be developed into anticancer drugs because they can easily be synthesized and structurally manipulated for selective development. The clarification of the mode of action of S5C and S6C may also be important in developing their applications.

Therefore, the major goal of our study was to compare several parameters of apoptosis induced in A549 cells by the fatty acids, S5C, S6C and their analogs (S5 and S6) (Fig. 1). We demonstrated that S5C- and S6C-induced A549 cell apoptosis was accompanied by DNA damage and the inhibition of DNA replication.

\section{Materials and methods}

Chemicals. The PI/RNase staining buffer for cell cycle analysis and the Annexin-FITC kit for apoptosis were from BD Biosciences Pharmingen, USA. DMSO and PBS (pH 7.4) were purchased from Sigma Chemical Co. RPMI-1640, fetal bovine serum (FBS), and penicillin-streptomycin and trypsinEDTA were obtained from Hyclone Laboratories (Logan, UT). CCK-8 was purchased from Dojin Laboratories (Osaka, Japan). All other chemicals were from an analytical reagent grade.

Preparation of S5C, S6C and their ester analogs (S5 and S6). S5C and S6C were isolated from Red Alga Gracilaria verrucosa and obtained from the laboratory of Dr J.H. Jung. Stock solutions of the samples were prepared in dimethyl sulfoxide (DMSO) and kept at $4^{\circ} \mathrm{C}$. Further dilutions were made immediately prior to each experiment.

Cell lines. A549 cells obtained from the American Type Culture Collection (ATCC) were cultured in RPMI-1640 supplemented with $10 \%$ fetal bovine serum at $37^{\circ} \mathrm{C}(5 \%$ $\mathrm{CO}_{2}$ ) in a humidified atmosphere.

Cell viability and proliferation assay. A549 cells were plated at $5 \times 10^{3}$ cells into each well of a 96-well microplate. After a 24-h incubation, S5C, S6C and their analogs (S5 and S6) were added to each well as treatment at various concentrations and an appropriate volume of the drug vehicle (DMSO) was used as the control. The plates were incubated further for $48 \mathrm{~h}$. Then, $10 \mu \mathrm{l}$ of CCK-8 reagent was added and incubated for a further $2 \mathrm{~h}$. The cell viability was assessed by WST-8 [2-(2-methoxy-4-nitrophenyl)-3-(4-nitrophenyl)-5(2,4-disulfophenyl)-2H-tetrazolium], and was reduced by dehydrogenases in the cells to give a yellow-colored product (formazan), which is soluble in cell culture medium. The optical density for living cells was read at $450 \mathrm{~nm}$ in a multimicroplate reader (synergy HT, BIO-TEK ${ }^{\circledR}$ ) (16).

For the cell proliferation assay, cells were seeded at $5 \times 10^{3} / \mathrm{ml}$ media in 96-well plates and treated with or without S5C, S6C, S5 and S6 (75, 150 and $300 \mu \mathrm{M})$ at various times. Each experiment was repeated at least three times.

Measurement of apoptotic morphology. A549 cells were distributed ( $1 \times 10^{5}$ cells/well) into a 24 -well plate and allowed to adhere overnight. The cells were treated with $\mathrm{S} 5 \mathrm{C}$ and $\mathrm{S} 6 \mathrm{C}$ (with an $\mathrm{IC}_{50}$ concentration), respectively, for the relevant times. Non-treated wells received an equivalent volume of DMSO $(<0.1 \%)$. Optic phase-contrast photographs were taken with a Nikon ${ }^{\mathrm{TM}}$ Phase Contrast-2, ELWD 0.3 inverted microscope. Each experiment was repeated at least three times.

Annexin V-FITC/PI apoptotic analysis. The cells $\left(5 \times 10^{5}\right.$ cells in $60-\mathrm{mm}^{2}$ dishes) treated with or without S5C and S6C were collected by trypsinization and washed with cold PBS via centrifugation. The pellets were suspended in $100 \mu 1$ of binding buffer and stained with $5 \mu \mathrm{l}$ of Annexin V-FITC (BD PharMingen) and $10 \mu \mathrm{l}$ of PI $(50 \mu \mathrm{g} / \mathrm{ml})$ for $15 \mathrm{~min}$ at room temperature in the dark. Thereafter the samples were read in a FACSCalibur flow cytometer immediately. In each analysis, 10,000 events were recorded. Analyses were performed by CellQuest software (Becton-Dickinson Instruments, Franklin Lakes, NJ).

DNA content analysis. The cells $\left(5 \times 10^{5}\right.$ cells in $60-\mathrm{mm}^{2}$ dishes) treated with or without S5C and S6C were collected by trypsinization and washed with cold PBS via centrifugation. The cells were suspended in PBS and fixed with $70 \%$ ethanol (v/v). Samples were washed with PBS and stained with $\mathrm{PI} / \mathrm{RNase}$ staining buffer (BD PharMingen) for $15 \mathrm{~min}$ at $4^{\circ} \mathrm{C}$. The cells in different phases of the cell cycle were analyzed using a FACScan flow cytometer analysis system (Becton-Dickinson, San Jose, CA), and 20,000 events were analyzed for each sample. The percentage of cells residing in different phases of the cell cycle were determined using Modfit software (Becton-Dickinson Instruments). All experiments were performed in duplicate and yielded similar results.

$\left[{ }^{3} \mathrm{H}\right]$ thymidine incorporation assay. The $\left[{ }^{3} \mathrm{H}\right] \mathrm{dTTP}$ incorporation was performed as previously described (17). Briefly, A549 cells were applied to 12-well plates in a growth medium (RPMI-1640 + 10\% FBS). After the cells had grown to 70-80\% confluence, they were rendered quiescent by incubation for $24 \mathrm{~h}$ in RPMI-1640 containing 2\% FBS. RPMI supplemented with $10 \% \mathrm{FBS}$ and an $\mathrm{IC}_{50}$ concentration of the sample (or control) were added to cells and the cultures were incubated 


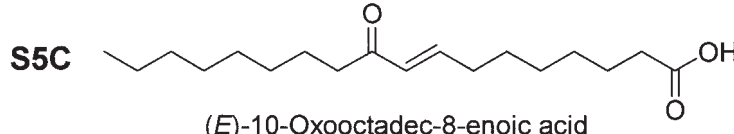

S6C<smiles>CCCCCCCC=CC(=O)CCCCCCCC(=O)O</smiles>

(E)-9-Oxooctadec-10-enoic acid

S5

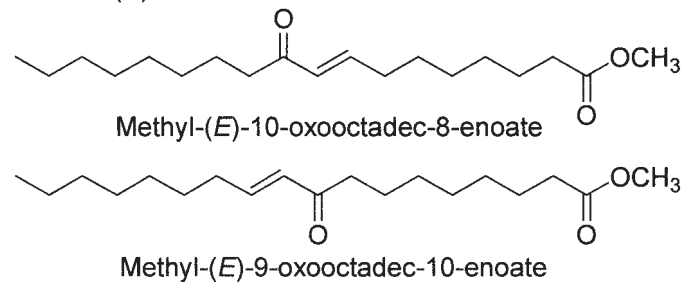

Figure 1. The structures of S5C, S6C, S5 and S6.

for 21 and $45 \mathrm{~h}$. [ $\left.{ }^{3} \mathrm{H}\right] \mathrm{dTTP}$ was added at $1 \mu \mathrm{Ci} / \mathrm{ml}(1 \mu \mathrm{Ci}=$ $37 \mathrm{kBq}$ ) and incubated further for $3 \mathrm{~h}$. Incorporated $\left[{ }^{3} \mathrm{H}\right] \mathrm{dTTP}$ was extracted in cell lysis buffer and measured in a liquid scintillation counter.

Single-cell gel electrophoresis. To examine the DNA damage in these single-cell suspensions, we performed an alkaline single-cell gel electrophoresis (comet assay). The comet assay was based on the protocol proposed by Singh et al $(8,18)$ with some modification. Each step was carried out under indirect light. Briefly, the cells (treated with or without S5C and $\mathrm{S} 6 \mathrm{C}$ for 24 and $48 \mathrm{~h}$, respectively) were pelleted and then resuspended in a $0.5 \%$ low melting point agarose gel at $37^{\circ} \mathrm{C}$. Thereafter, they were layered on a frosted microscope slide previously coated with a thin layer of $1 \%$ normal melting agarose gel and kept for $10 \mathrm{~min}$ on ice. After solidification, the slides were immersed in lysing solution $(2.5 \mathrm{M} \mathrm{NaCl}$, $100 \mathrm{mM}$ EDTA, $10 \mathrm{mM}$ Tris, $\mathrm{pH}$ 10, 1\% Triton $\mathrm{X}-100$ and $10 \% \mathrm{DMSO}$ for $1 \mathrm{~h} 30 \mathrm{~min}$ at $\left.4^{\circ} \mathrm{C}\right)$. The slides were then incubated in an alkaline buffer $\left(0.3 \mathrm{M} \mathrm{NaOH}\right.$ and $1 \mathrm{mM} \mathrm{Na}_{2}$ EDTA) for $40 \mathrm{~min}$ at $4^{\circ} \mathrm{C}$. Electrophoresis was carried out for $40 \mathrm{~min}$ at $25 \mathrm{~V}$. After electrophoresis, the slides were washed with $0.4 \mathrm{M}$ Tris ( $\mathrm{pH} 7.5)$, stained with ethidium bromide $(2 \mu \mathrm{g} / \mathrm{ml})$ and observed under fluorescent microscopy (Leica DM LB2).

The data were analyzed using the Komet 5.5 software. Olive Tail Moment (OTM) approved by Olive was used to evaluate DNA damage. OTM, expressed in arbitrary units, is calculated by multiplying the percent of DNA (fluorescence) in the tail by the length of the tail in $\mu \mathrm{m}(19,20)$. The tail length is measured between the edge of the Comet head and the end of its tail. A major advantage of using the OTM as an index of DNA damage is that the amount of damaged DNA and the distance of migration of the genetic material in the tail are represented by a single number (21).

Statistical analysis. Each experiment was repeated at least three times and the results were expressed as mean \pm SEM in some quantitative experiments. The results reported were obtained from at least three independent experiments with similar results.
(A):

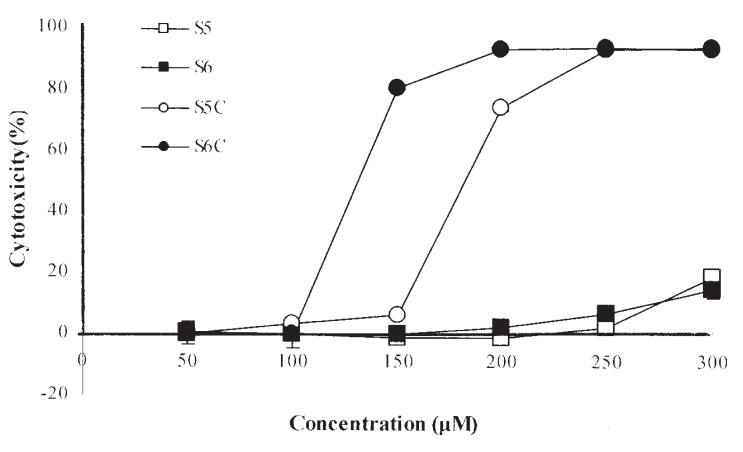

(B):

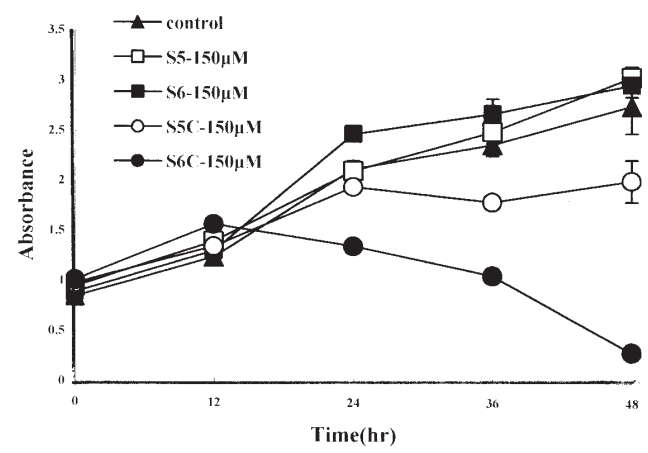

Figure 2. Effects of S5C and S6C on the viability and proliferation of A549 cells. A549 cells were treated with various concentrations of S5C, S6C, S5 and S6 for $48 \mathrm{~h}$ (A) or with 0 and $150 \mu \mathrm{M}$ of S5C, S6C, S5 and S6 for 12, 24,36 and $48 \mathrm{~h}$, respectively (B). Relative cell viability was determined by WST-8 and is presented as the percentage of control cells. The data are shown as means $\pm \mathrm{SD}$ of three independent experiments.

\section{Results}

S5C and S6C induced the inhibition of A549 cell growth and apoptotic cell death. To explore the cytotoxicity of S5C, S6C and their ester analogs (S5 and S6), we started our study with a cytotoxicity assay to determine $\mathrm{IC}_{50}$ in $\mathrm{A} 549$ cells, a human lung cancer cell line. The water-soluble tetrazolium salt, WST-8, was used as an indicator in the cytotoxicity assay (16). As shown in Fig. 2A, treatment of A549 cells with various concentrations of $\mathrm{S} 5 \mathrm{C}$ and $\mathrm{S} 6 \mathrm{C}$ for $48 \mathrm{~h}$ caused a concentration-dependent decrease in cell number, with an $\mathrm{IC}_{50}$ of 169 and $139 \mu \mathrm{M}$ (S5C and S6C, respectively), but their ester analogs (S5 and S6) did not show strong cytotoxicity. Cell proliferation assay was used to investigate the growth inhibitory effect of S5C and S6C on A549 cells. The proliferation of S5C- and S6C-treated cells gradually increased to $12 \mathrm{~h}$ and significantly decreased at $24 \mathrm{~h}$, whereas the control- and their ester analog-treated cells maintained an exponential proliferation state. However, with a low concentration of S5C and S6C (up to $75 \mu \mathrm{M}$ ) cell growth was not affected, and with a higher concentration of S5C and S6C (up to $300 \mu \mathrm{M}$ ) the cells were killed. Therefore, only the data using $150 \mu \mathrm{M}$ are shown in Fig. 2B. 
(A)

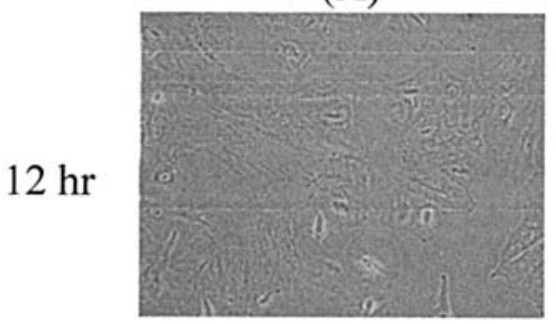

(D)

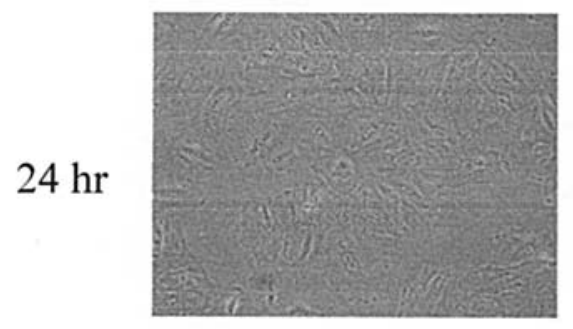

(B)

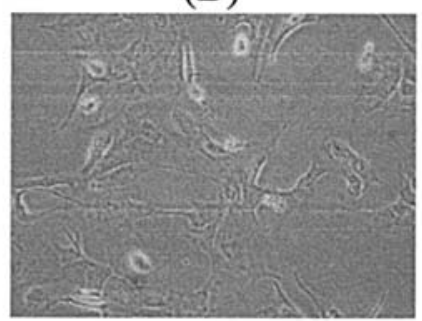

(E)

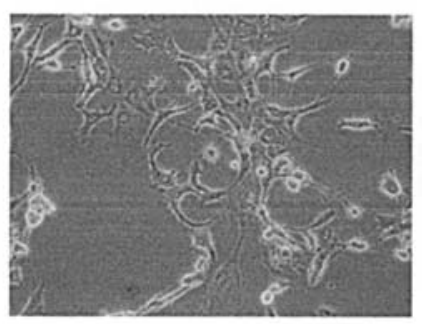

(C)

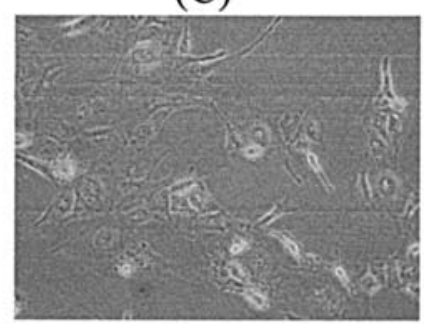

(F)

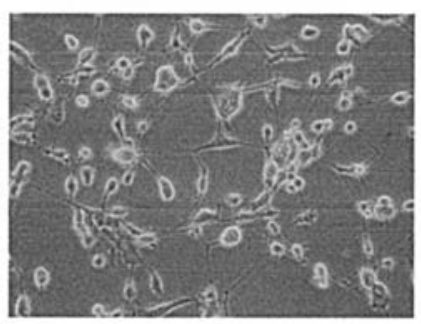

Figure 3. Morphological changes in A549 cells were observed under light microscopy. Exponentially growing cells were incubated either with vehicle alone for 12 (A) and $24 \mathrm{~h}(\mathrm{D}), 169 \mu \mathrm{M}$ of S5C for 12 (B) and $24 \mathrm{~h}(\mathrm{E})$ or $139 \mu \mathrm{M}$ of S6C for 12 (C) and $24 \mathrm{~h}$ (F). Magnification, x160.
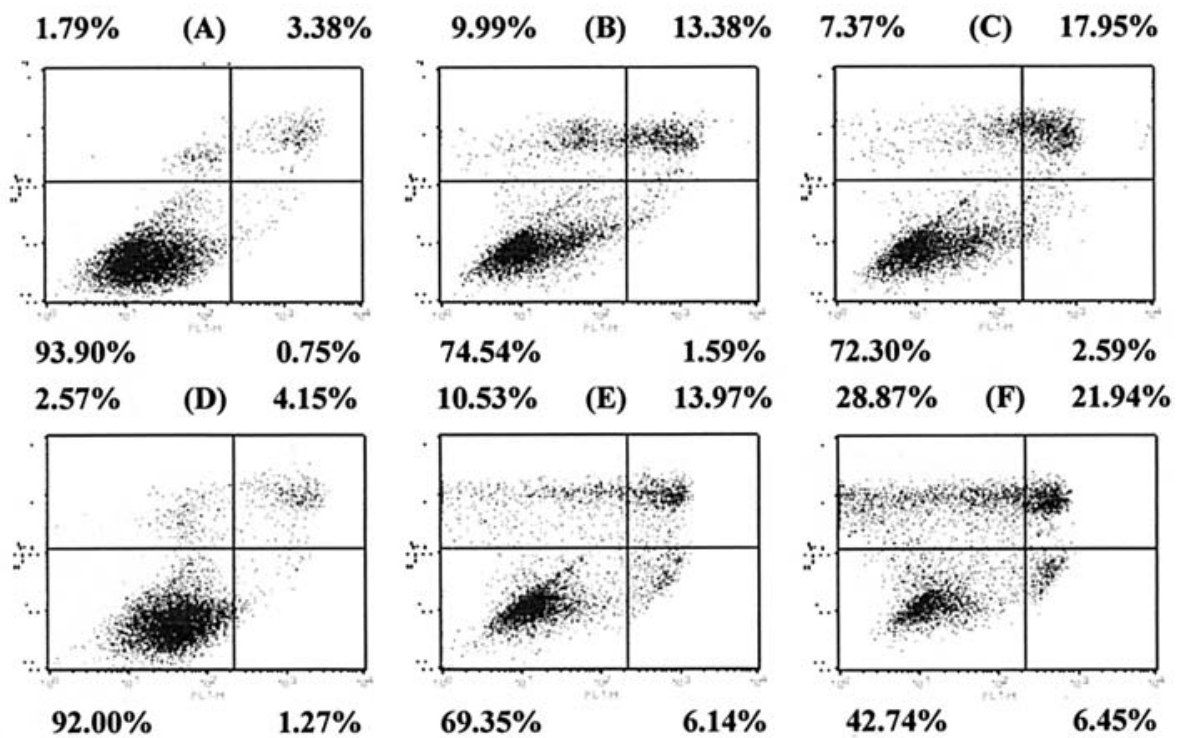

Figure 4. Measurement of apoptotic population induced by S5C and S6C. A549 cells were treated with vehicle alone for 24 (A) and $48 \mathrm{~h}$ (D), $169 \mu \mathrm{M}$ of S5C

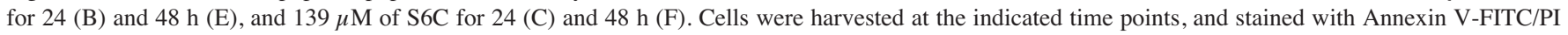
and analyzed for apoptosis by flow cytometry. As shown, the cell populations shown in the lower left represent living cells, the lower right represents earlier apoptotic cells, the upper right represents late apoptotic or necrotic cells and the upper left represents pre-necrotic cells. All experiments were performed in duplicate and gave similar results.

Changes in the cells treated with an $\mathrm{IC}_{50}$ concentration of S5C and S6C using light microscopy revealed morphological features of apoptosis. Under light microscopy, non-treated A549 cells spread regularly in the culture plates and grew to near confluence (Fig. 3A and D). After a 12-h treatment with the $\mathrm{IC}_{50}$ value of $\mathrm{S} 5 \mathrm{C}$ and $\mathrm{S} 6 \mathrm{C}$, some A549 cells floated, but the majority of the attached cells kept a normal cellular shape (Fig. 3B and C). After $24 \mathrm{~h}$, a significant proportion of the A549 cells dislodged from their plates and most of the remaining attached cells showed typical morphological changes corresponding to apoptosis, which was characterized by cellular shrinkage and disruption (Fig. 3E and F). Little or no detachment was observed in the control A549 cells.

An Annexin V and PI double staining assay was performed to obtain further evidence for the induction of apoptosis by S5C and S6C in A549 cells. Significant differences were observed between the control and treated cells. As shown in Fig. 4A, 93.90\% of vehicle alone-treated A549 cells were viable (Annexin $\mathrm{V}^{-} \mathrm{PI}-$ ) for $24 \mathrm{~h}$, and $\sim 0.75 \%$ were early apoptotic cells (Annexin $\mathrm{V}^{+} \mathrm{PI}^{-}$). In contrast, A549 cells 
Control

(A)

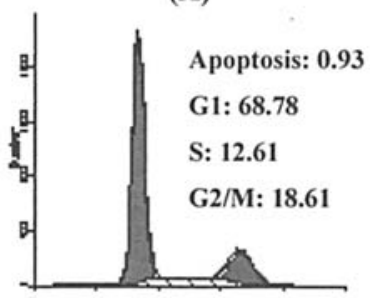

(D)

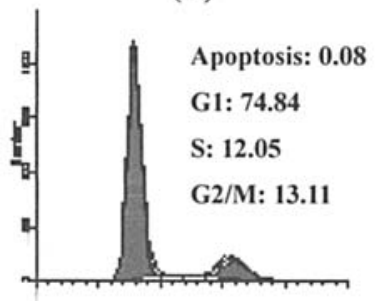

$169 \mu \mathrm{M}$ of $\mathrm{S} 5 \mathrm{C}$

(B)

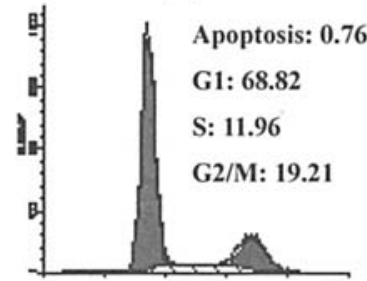

(E)

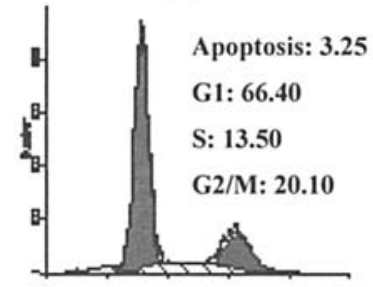

$139 \mu \mathrm{M}$ of $\mathrm{S} 6 \mathrm{C}$

(C)

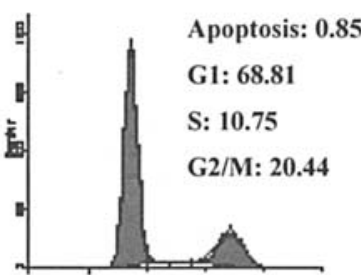

(F)

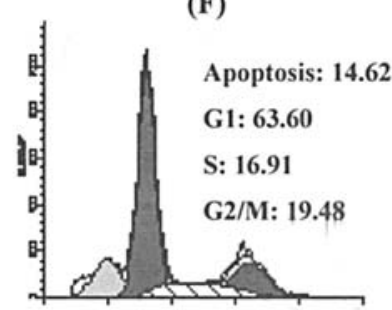

Figure 5. Effect of S5C and S6C on the cell cycle progression of A549 cells. A549 cells were treated with vehicle alone or with $169 \mu \mathrm{M}$ of S5C or $139 \mu \mathrm{M}$ of S6C for $24 \mathrm{~h}$ (A, B and C) and $48 \mathrm{~h}$ (D, E and F). The DNA content was analyzed by flow cytometry with PI staining. The cell cycle distribution was calculated as the percentage of cells containing apoptosis, G0/G1, S and G2/M phase. The data are of three independent experiments.

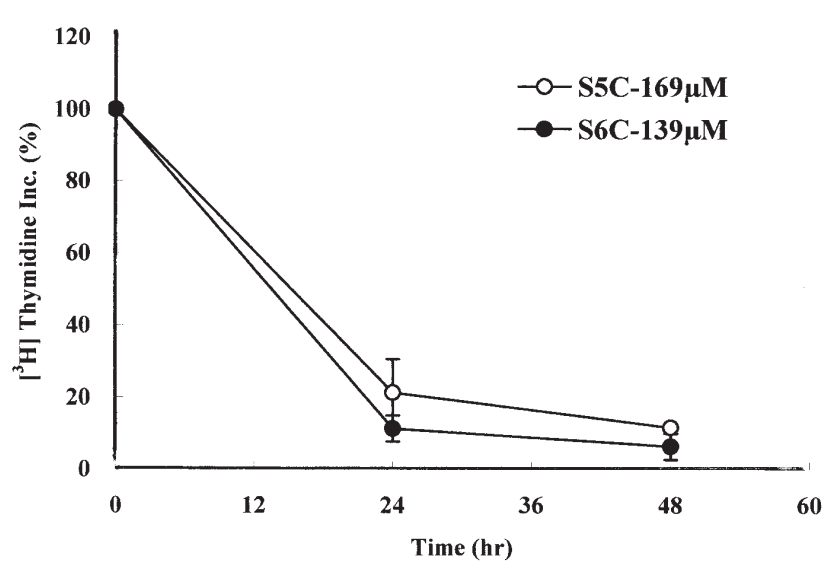

Figure 6. Inhibitory effect of S5C and S6C on $\left[{ }^{3} \mathrm{H}\right] \mathrm{dTTP}$ incorporation of A549 cells. A549 cells were either untreated (as a control, indicated by $0 \mathrm{~h}$ ), or pretreated with $169 \mu \mathrm{M}$ of S5C and $139 \mu \mathrm{M}$ of S6C for the indicated times. $\left[{ }^{3} \mathrm{H}\right] \mathrm{dTTP}$ was added, followed by an additional 3 -h incubation. The amount of $\left[{ }^{3} \mathrm{H}\right] \mathrm{dTTP}$ incorporated was analyzed by scintillation counting. Standard deviations are shown with error bars from a mean of at least three different experiments.

treated with $169 \mu \mathrm{M}$ of $\mathrm{S} 5 \mathrm{C}$ and $139 \mu \mathrm{M}$ of S6C showed a gradual increase of early apoptotic cells. After a 24-h treatment with S5C and S6C, only 74.54 and $72.30 \%$ of A549 cells were viable, while 1.59 and $2.59 \%$ were apoptotic, respectively (Fig. 4B and C). Furthermore, the proportion of apoptotic cells increased to 6.14 and $6.45 \%$ after a 48 -h incubation of $169 \mu \mathrm{M}$ of S5C and $139 \mu \mathrm{M}$ of S6C (Fig. 4E and $\mathrm{F}$ ). In addition, the percentage of late apoptotic cells (or necrotic cells) stained by Annexin V-FITC and PI (Annexin $\mathrm{V}^{+} \mathrm{PI}^{+}$) was also increased by treatment of S5C and S6C. Therefore, in comparison with the control cells, treated A549 cells displayed an increase in apoptosis in a time-dependent manner.
S5C-and S6C-induced apoptosis is associated with an increased $S$ phase population. The dysregulation of the cell cycle may be a reason to initiate apoptosis (22-24), and investigate whether the inhibition of A549 cell proliferation was mediated or a flow cytometry analysis of PI-stained A549 nuclei was performed. Since the $\mathrm{IC}_{50}$ value was $\sim 169$ and $139 \mu \mathrm{M}$ (S5C and S6C, respectively), A549 cells were treated with this concentration at various times. As shown in Fig. 5, S5C and S6C was able to perturb the cell cycle in a timedependent course. After a 48-h treatment, the percentage of cells in the $\mathrm{S}$ phase significantly increased from a control value of 12.05 to $13.50 \%$ and $16.91 \%$ in cells treated with S5C $(169 \mu \mathrm{M})$ and S6C $(139 \mu \mathrm{M})$, respectively. This increase occurred by decreasing the G0/G1 cell population. The population of the cells in the G2/M phase was not affected.

S5C and S6C inhibit DNA replication, associated with the induction of DNA damage. From the cell cycle assay result, we demonstrated that A549 cells treated with S5C and S6C accumulated in the $\mathrm{S}$ phase. Therefore, we hypothesized that they induced the A549 cell cycle arrest in S phase due to the inhibition of DNA replication. To confirm this hypothesis, we analyzed DNA replication in cells treated with S5C and S6C by determining the incorporation of $\left[{ }^{3} \mathrm{H}\right] \mathrm{dTTP}$. As shown in Fig. 6, after the 24-h treatment, S5C $(169 \mu \mathrm{M})$ and S6C $(139 \mu \mathrm{M})$ inhibited the $\left[{ }^{3} \mathrm{H}\right] \mathrm{dTTP}$ incorporation by $\sim 80$ and $90 \%$, respectively, in A549 cells, but did not show a timedependent manner until $48 \mathrm{~h}$ later. We hypothesized that DNA damage induced by S5C and S6C leads to the inhibition of DNA replication observed, which is then responsible for blockage of the S-phase progression. To test this hypothesis, we implemented the alkaline version comet assay. It is a sensitive method that evaluates DNA single-strand breaks at a single-cell level by the increased tail of DNA migration. Fig. 7B is a photomicrograph of DNA migration patterns in 
(A)

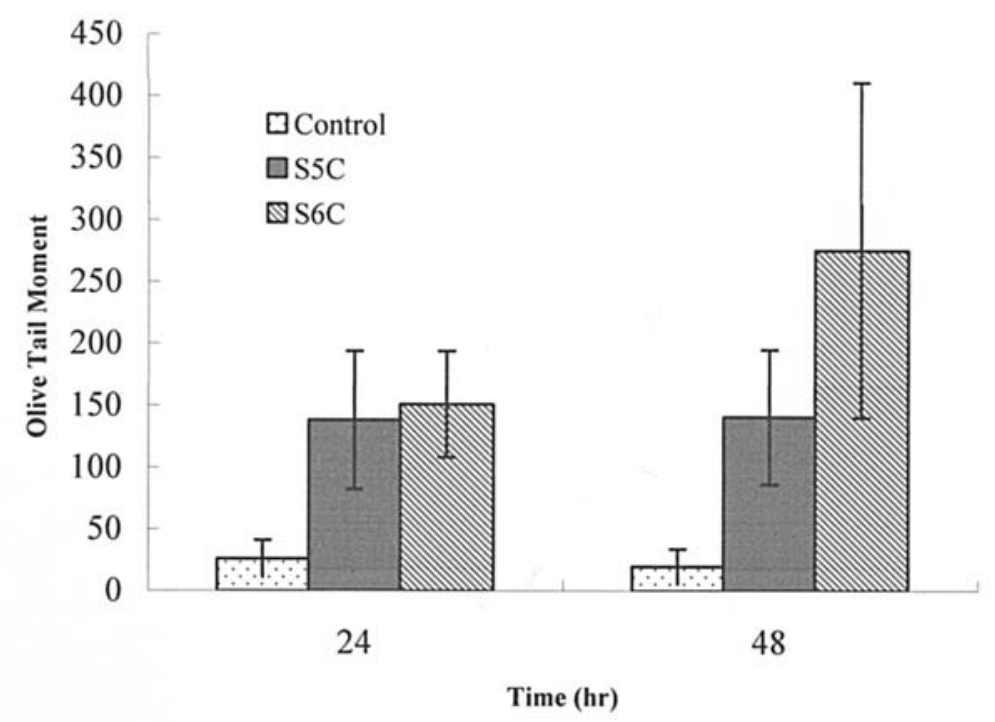

(B)

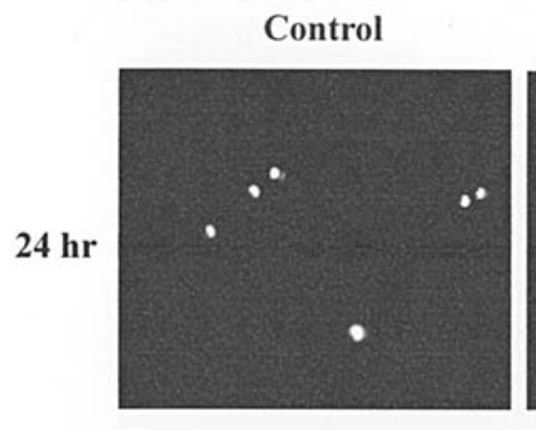

$169 \mu \mathrm{M}$ of S5C
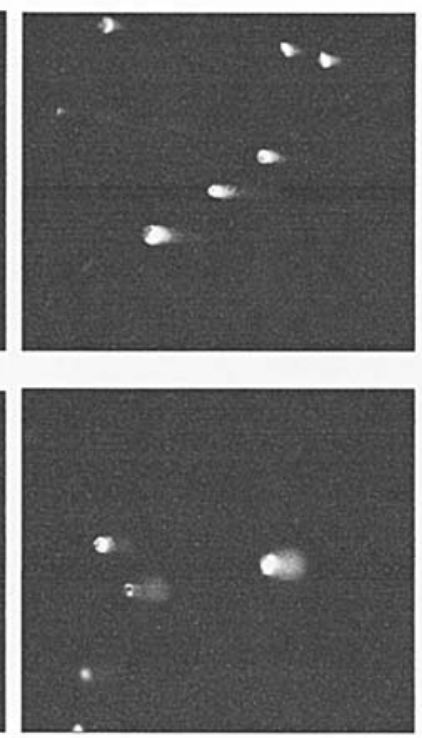

$139 \mu \mathrm{M}$ of $\mathrm{S} 6 \mathrm{C}$
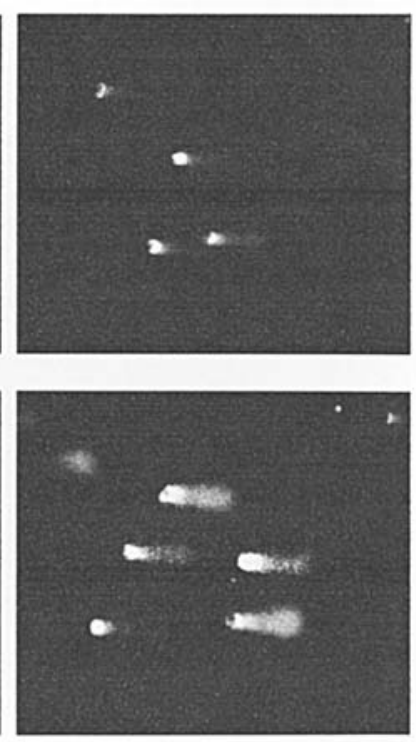

Figure 7. S5C and S6C induce DNA strand breaks in A549 cells. (A) Olive Tail Moment of DNA from A549 cells treated with $169 \mu \mathrm{M}$ of S5C or $139 \mu \mathrm{M}$ of S6C, respectively. (B) DNA single-strand breaks induced by S5C and S6C in A549 cells. Cells are incubated with or without $169 \mu \mathrm{M}$ of S5C and 139 $\mu \mathrm{M}$ of S6C. The comet assay was determined as described in Materials and methods. Results are from three independent experiments.

A549 cells. When cells were treated with $169 \mu \mathrm{M}$ of S5C and $139 \mu \mathrm{M}$ of S6C for $24 \mathrm{~h}$, DNA damage, as indicated by the increased olive tail moment in our data (Fig. 7A), was observed in the treated cells as increased tails of DNA migration in the photomicrograph. After a 48-h treatment with S5C and S6C, almost the entire population of A549 cells contained damaged DNA. The clear DNA fragmentation was noted throughout the experiment, with OTM values ranging from 138.23 to 140.89 in S5C-treated cells and from 151.05 to 276.32 in S6C-treated cells. At the same time after 48 -h treatments, the $\mathrm{S}$ population had slightly increased (Fig. 6), and apoptosis was barely detectable (Fig. 5). S5C and S6C therefore induced the DNA strand breaks before S phase accumulation and apoptotic induction.

\section{Discussion}

The results indicated that S5C and S6C showed cytotoxicity on A549 cells and inhibited its proliferation significantly after a 24-h incubation. In contrast, compared with S5C and $\mathrm{S} 6 \mathrm{C}$, the cells were not as sensitive with the ester derivatives S5 and S6. We suggest that the acid group of these compounds is important for cell cytotoxicity and the different position of the enone group which also affects their activity. These 
results suggest that $\mathrm{S} 5 \mathrm{C}$ and $\mathrm{S} 6 \mathrm{C}$ inhibit the proliferation of A549 cells in the early phase while introducing apoptosis in the late phase during treatment because the proliferation of the A549 cells treated by S5C and S6C was stopped, increased at $12 \mathrm{~h}$ and then decreased. Therefore, a series of assays focusing on apoptosis were carried out in this study.

A variety of methods have been reported for monitoring different steps in apoptotic pathways $(25,26)$. The initiating effect of S5C and S6C on the A549 cell apoptosis was confirmed by observing the morphological changes under light microscopy. The predominant pattern of the abnormal metaphase morphology in the cells exposed to S5C and S6C suggests a pronounced and specific impairment with typical apoptotic patterns including a reduction in the volume and fragmentation of cells (Fig. 3). The result of the Annexin VFITC/PI double staining assay indicated that S5C and S6C induced early apoptosis in A549 cells at $48 \mathrm{~h}$ with different intensities (Fig. 4). Based on these data, we conclude that S5C and S6C exhibit their anti-proliferation and cytotoxicity effects on A549 cells by triggering apoptosis in the cells. However, to gain clear insight into the mechanisms of S5Cand $\mathrm{S} 6 \mathrm{C}$-induced apoptosis more work on expression levels, and the enzyme activities of apoptotic and cell cycle regulators should be carried out.

Since the activation and execution of apoptosis are regulated by complex molecular mechanisms, numerous points of interaction between the regulatory pathway of the cell cycle and apoptosis exist (27). We observed a similar accumulation of A549 cells at the $\mathrm{S}$ phase upon their treatment $(24,28)$. S5C and S6C at the $\mathrm{IC}_{50}$ concentration induce S-phase arrest at $48 \mathrm{~h}$, which is associated with apoptosis induction (Fig. 5). During the $\mathrm{S}$ phase of cell division, the cycle cells replicate their DNA. In this phase, chromosomal DNA is replicated only once as a prelude to its segregation with the daughter cells at mitosis. If DNA replication is blocked by an inhibitor or the template is damaged by radiation or other factors, signals are generated that can induce cell cycle arrest or apoptosis $(29,30)$. Therefore, based on the result we hypothesized that S5C and S6C induced S-phase arrest and apoptosis correlated with their effect on DNA replication.

It was of note to find that a $24-\mathrm{h}\left[{ }^{3} \mathrm{H}\right] \mathrm{dTTP}$ incorporation was inhibited by S5C and S6C treatment after administration (Fig. 6). Results from the comet assay showed that $~ 90 \%$ of the cell population contained DNA strand breaks after only $24 \mathrm{~h}$ of incubation with S5C and S6C (Fig. 7). These results support the hypothesis that the inhibition of DNA replication is caused by DNA damage. However, according to the controls no increase of early apoptotic cells after a 24-h treatment of S5C and S6C was noted, suggesting that the apoptosisassociated DNA fragmentation had not yet occurred. Moreover, at $48 \mathrm{~h}$ DNA was damaged significantly in the treated cells while the early apoptotic cells increased insignificantly. Collin et al and Speit et al comment that the single-strand breaks observed in the alkaline version are not the most noteworthy of DNA lesions because they are rapidly repaired and not regarded as a significantly lethal or mutagenic lesion $(31,32)$. However, through the process of apoptosis any cell which is severely damaged beyond the capacity of the DNA repair system or cannot be repaired is to be eliminated. Therefore, we conclude that S5C and S6C induce DNA strand breaks and inhibit the incorporation of $\left[{ }^{3} \mathrm{H}\right] \mathrm{dTTP}$, before any cell cycle change has occurred. It indicated that S5C and S6C induced cell cycle arrest in order to allow DNA repair. As expected, these mechanisms result in S-phase arrest and apoptosis.

In conclusion, our study provides experimental evidence that S5C- and S6C-induced A549 cell apoptosis was accompanied by DNA damage. S5C and S6C also induced the $\mathrm{S}$-phase arrest and inhibition of DNA replication. However, the mechanism of DNA breakage remains elusive, and further investigation needs to be conducted, such as the target protein that the compound-induced apoptosis focuses on and the pathway chosen.

\section{Acknowledgements}

This work was partially supported by the BK21 project of the Ministry of Education of Korea, and by the Inje FIRST project of Inje University.

\section{References}

1. Newman DJ, Cragg GM and Snader KM: Natural products as sources of new drugs over the period 1981-2002. J Nat Prod 66: 1022-1037, 2003.

2. Rayl AJS: Oceans: medicine chests of the future? Scientist 13: 1-4, 1999.

3. Haefner B: Drugs from the deep: marine natural products as drug candidates. Drug Discov Today 8: 536-544, 2003

4. Dang TH, Lee HJ, Yoo ES, Shinde PB, Lee YM, Hong JK, Kim DK and Jung JH: Anti-inflammatory constituents of the red alga Gracilaria verrucosa and their synthetic analogs. J Nat Prod 71: 232-240, 2008.

5. Lynn WS, Sachs C Jr, Jacobs A, Lynn DG and Phillips NG: Source and function of keto elaidic acids from lungs of cotton workers. Arch Environ Health 41: 197-207, 1986.

6. Han Z, Wei W, Dunaway S, Darnowski JW, Calabresi P, Sedivy J, Hendrickson EA, Balan KV, Pantazis P and Wyche JH: Role of p21 in apoptosis and senescence of human colon cancer cells treated with camptothecin. J Biol Chem 277: 17154-17160, 2002.

7. Kowalska-Loth B, Girstun A, Piekielko A and Staron K: SF2/ASF protein inhibits camptothecin-induced DNA cleavage by human topoisomerase I. Eur J Biochem 269: 3504-3510, 2002.

8. Singh NP, McCoy MT, Tice RR and Schneider EL: A simple technique for quantitation of low levels of DNA damage in individual cells. Exp Cell Res 175: 184-191, 1988.

9. Hartman A, Agurell E, Beevers C, Brendler-Schwaab S, Burlinson B, Clay P, Collons A, Smith A, Speit G, Thyband V and Tice RR: Recommendations for conducting the in vivo alkaline Comet assay. Mutagenesis 18: 45-51, 2003.

10. Singh NP, Danner DB, Tice RR, Brant L and Schneider EL: DNA damage and repair with age in individual human lymphocytes. Mutat Res 237: 123-130, 1990.

11. Zhang YJ, Ahn EY, Jiang YH, Kim DK, Kang SG, Wu CF, Kang SW, Park JS, Son BW and Jung JH: 3-Chloro-2,5dihydroxybenzyl alcohol activates human cervical carcinoma HeLa cell apoptosis by inducing DNA damage. Int J Oncol 31 : 1317-1323, 2007.

12. Hengartner MO: The biochemistry of apoptosis. Nature 407: 770-776, 2000.

13. Brown JM and Wounters BG: Apoptosis, p53, and tumor cell sensitivity to anticancer agents. Cancer Res 59: 1391-1399, 1999.

14. Earnshaw WC: Nuclear changes in apoptosis. Curr Opin Cell Biol 7: 337-343, 1995.

15. Fisher DE: Apoptosis in cancer therapy: crossing the threshold. Cell 78: 539-542, 1994.

16. Tominaga $\mathrm{H}$, Ishiyama $\mathrm{M}$, Ohseto $\mathrm{F}$, Sasamoto $\mathrm{K}$, Hamamoto $\mathrm{T}$, Suzukj K and Watanabe M: A water-soluble tetrazolium salt useful for colorimetric cell viability assay. Anal Commun 36: 47-50, 1999 
17. Lin SY, Liu JD, Chang HC, Yeh SD, Lin CH and Lee WS: Magnolol suppresses proliferation of cultured human colon and liver cancer cells by inhibiting DNA synthesis and activating apoptosis. J Cell Biochem 84: 532-544, 2002.

18. Singh NP: Microgels for estimation of DNA strand breaks, DNA protein crosslinks and apoptosis. Mutat Res 455: 111-127, 2000.

19. Hellman B, Vaghef $\mathrm{H}$ and Bostrom B: The concepts of tail moment and tail inertia in the single cell gel electrophoresis assay. Mutat Res 336: 123-131, 1995.

20. Rojas E, Lopez M and Valverde M: Single cell gel electrophoresis assay: methodology and applications. J Chromatogr B Biomed Sci Appl 722: 225-254, 1999.

21. Ashby J, Tinwell H, Lefevre P and Browne M: The single cell gel electrophoresis assay for induced DNA damage (Comet assay): measurement of tail length and moment. Mutagenesis 10: 85-90, 1995.

22. Lee S, Christakos S and Small MB: Apoptosis and signal transduction: clues to a molecular mechanism. Curr Opin Cell Biol 5: 286-291, 1993.

23. Dou QP: Putative roles of retinoblastoma protein in apoptosis. Apoptosis 2: 5-8, 1997.

24. Smith DM, Gao G, Zhang X, Wang G and Dou QP: Regulation of tumor cell apoptotic sensitivity during the cell cycle (Review). Int J Mol Med 6: 503-507, 2000.
25. Kiechle FL and Zhang X: Apoptosis: biochemical aspects and clinical implications. Clin Chim Acta 326: 27-45, 2002.

26. Otsuki Y, Li Z and Shibata MA: Apoptotic detection methods from morphology to gene. Prog Histochem Cytochem 38: 335-339, 2003.

27. Evan GI and Vousden KH: Proliferation, cell cycle and apoptosis in cancer. Nature 411: 342-348, 2001.

28. Orren DK, Petersen LN and Bohr VA: Persistent DNA damage inhibits S-phase and G2 progression and results in apoptosis. Mol Biol Cell 8: 1129-1142, 1997.

29. Pizer ES, Chrest FJ, DiGiuseppe JA and Han WF: Pharmacological inhibitors of mammalian fatty acid synthase suppress DNA replication and induce apoptosis in tumor cell lines. Cancer Res 58: 4611-4615, 1998.

30. Jiang YH, Ahn EY, Ryu SH, Kim DK, Park JS and Kang SW: Mechanism of cell cycle arrest by $(8 E, 13 Z, 20 Z)$-strobilinin/ (7E,13Z,20Z)-felixinin from a marine sponge Psammocinia sp. Oncol Rep 14: 957-962, 2005.

31. Collins AR, Dobson VL, Dusinska M, Kennedy G and Stetina R: The comet assay: what can it really tell us? Mutat Res 375 : 183-193, 1997.

32. Speit G, Dennog C and Lampl L: Biological significance of DNA damage induced by hyperbaric oxygen. Mutagenesis 13: $85-87,1998$. 